Kansas State University Libraries

New Prairie Press

International Symposium for Innovative

Teaching and Learning
2017 International Symposium on Innovative Teaching and Learning

\title{
Future Entrepreneurship Education for Students in China
}

Yang Song

Jilin University, y.songuva@gmail.com

Dafna Schwartz

Ben-Gurion University of the Negev, dafnasch@som.bgu.ac.il

Follow this and additional works at: https://newprairiepress.org/isitl

Part of the Educational Leadership Commons, Educational Methods Commons, and the Entrepreneurial and Small Business Operations Commons

cc) (1) (2)

This work is licensed under a Creative Commons Attribution-Noncommercial-Share Alike 4.0

License.

\section{Recommended Citation}

Song, Yang and Schwartz, Dafna (2017). "Future Entrepreneurship Education for Students in China," International Symposium for Innovative Teaching and Learning. https://doi.org/10.4148/2573-4911.1009

This Presentation is brought to you for free and open access by the Conferences at New Prairie Press. It has been accepted for inclusion in International Symposium for Innovative Teaching and Learning by an authorized administrator of New Prairie Press. For more information, please contact cads@k-state.edu. 


\title{
Future Entrepreneurship Education for students in China
}

Yang Song, Dafna Schwartz

\begin{abstract}
Due to the increasing needs of entrepreneurial activities in China, entrepreneurship education is becoming one of the most important topics for university students. This project reviews the current situation of Chinese entrepreneurship education and problems that exist. We focus on factors that influence the appropriateness of entrepreneurship studies to the needs and expectations of university students in China. We aim at discovering how to improve the entrepreneurial traits and business needs of the students from entrepreneurship studies. We aim at highlight the disparity between the supply and the expectations from entrepreneurship programmes in Chinese universities. Furthermore, we will compare the entrepreneurial traits of Israeli students and Chinese students in order to find out the similarities and differences. We will improve the Chinese future entrepreneurship education by learning the theories and practices from Israeli entrepreneurship education. Our final goal of this project is to apply entrepreneurship education in general to different filed students.
\end{abstract}

Keywords: entrepreneurship education; entrepreneurial intention; entrepreneurial traits; China 